\author{
E.A. Kostina ${ }^{1}$, G.K. Tleuzhanova ${ }^{2}$, D.K. Dzholdanova ${ }^{2, *}$ \\ ${ }^{l}$ Novosibirsk State Pedagogical University, Russia; \\ ${ }^{2}$ Karagandy university of the name of academician E.A. Buketov, Kazakhstan \\ (E-mail:mit1dd5@mail.ru) \\ Scopus Authors ID: $57193693732^{I}, 57193699082^{2}$ \\ ORCID: 0000-0002-1428-7095 ${ }^{1}, 0000-0003-2302-1595^{2}, 0000-0003-4940-4412^{3}$
}

\title{
The role of the teacher's acmeological competence in the context of trilingual education
}

\begin{abstract}
The article discusses the concept of the «acmeological competence» and its role in the context of trilingual education. The policy of trilingual education is described, the insufficient level of the English language proficiency among secondary school teachers is noted and the need for the development of a multilingual personality is revealed. The authors come to the conclusion that in order to realize this need, it is impossible to do without the acmeological competence, which stimulates the development of such personal qualities as selfrealization, self-development and self-improvement. This suggests that a person should constantly develop himself in order to achieve good results in professional activities. However, the processes of self-realization, self-development and self-improvement are not particularly important tasks for all people. These processes become important when a person faces the problem of solving professional or life problems. Thus, the authors highlight the fact that every adult should set himself difficult tasks in order to achieve personal and professional growth. In addition to the acmeological competence, the article examines such concepts as «acmeological ability», "professionalism of activity» and «professionalism of the individual», which also play an important role in the professional formation and in the development of personality. In general, according to the authors, the development of a multilingual personality, which is a task in the trilingual education, requires a teacher to be highly motivated in the professional activity.
\end{abstract}

Keywords: acmeological competence, trilingual education, acmeological ability, polycultural and multilingual personality.

\section{Introduction}

Today, education in Kazakhstan is aimed at implementing the policy of trilingualism. In other words, it is focused on mastering the Kazakh, Russian and English languages by Kazakhstanis.

As the First President of our country N.A. Nazarbayev said in his Message of January 10, 2018, «the future of Kazakhstanis lies in fluency in the Kazakh, Russian and English languages. Graduates of Kazakhstani schools must speak three languages at the level necessary for life and work in the country and in the global world» [1]. This thought runs like a golden thread in almost all the Messages of N.A. Nazarbayev to his people, which indicate special attention and care to the problem of language development in Kazakhstan.

Trilingualism policy is the way of the Republic of Kazakhstan to enter the world community. Learning English is not a protest to the native state language, but one of the ways to enter this world community. The policy of trilingual education does not give us the right to forget about our native Kazakh language, but, on the contrary, requires us to pay due attention and respect to our mother tongue.

Considering the policy of trilingual education, it is impossible not to mention that Kazakhstan is a multilingual country, and that bilingualism, characteristic of our society, is qualitatively transformed into multilingualism.

Currently, in schools of Kazakhstan physics, chemistry, biology and computer science classes are conducted in English; and, in the future, as we suppose, other school subjects will be taught in English as well. In general, teaching at schools is conducted in three languages: Kazakh, Russian and English. However, unfortunately, in the data of the National Report of the Ministry of Education and Science of the Republic of Kazakhstan on the state and development of the education system of the Republic of Kazakhstan, a weak level of the English proficiency by subject teachers is noted, which can lead to a decrease in the quality of teaching of the subjects themselves. It follows from this that the task of teacher language training remains paramount.

\footnotetext{
*Corresponding author's e-mail: mit1dd5@mail.ru
} 
For complete mastery of a foreign language, as we know from the theory of intercultural communication, it is necessary to familiarize the people who speak this language with the culture and traditions and involve them in a foreign language environment. And this means that it is necessary to develop a multicultural and multilingual personality, which is the task of multilingual education.

Nursultan Nazarabayev said that modern society required the development of teaching new skills and competencies and stressed the need for trilingual education, i.e. mastering the native Kazakh, the second Russian and the international English languages.

The strategic development plan of the Republic of Kazakhstan until 2025, approved by the decree of the First President of the Republic of Kazakhstan dated February 15, 2018, notes that «the development of human capital with high-quality and in-demand skills of the $21^{\text {st }}$ century is a priority task, which the further growth of the economy of Kazakhstan will depend on. Competencies of the new era include the willingness to continuously learn and master the necessary skills. Technological renewal and digitalization are impossible without the availability of the competent personnel who effectively use their working hours and are able to apply technologies and knowledge, improve processes and implement innovations» [2]. By 2025, it is expected to develop the functional literacy, form modern skills and competencies that are in demand by labor markets in the short, medium and long term, continuously improve skills and competencies throughout life. In addition, in this document, «the key conditions for the development of human capital include training of future workers in high-quality and in-demand skills and competencies» [2].

\section{Experimental part}

Interpreting the above, we correlate «training future employees in high-quality and in-demand skills and competencies», or rather, bring them closer to the concept of the «acmeological competence», the formation of which is the goal of our research. And this means that without the teacher's acmeological competence in the context of trilingual education, the implementation of the tasks of the state language policy will be insufficiently effective.

Let us consider the concept of the «acmeological competence» in a more detailed way.

L.V. Abdalina and N.A. Filonova note that the acmeological competence is the teacher's competence that stands in the way of implementing such personal qualities of an individual as self-realization, selfknowledge, self-improvement, self-development and self-determination. All these qualities are united by the first part of their name «self», which, we believe, says that a person should and can develop his own capabilities and he needs to work on this himself.

The first part of these self-processes tells us that the personality itself is the moving force for the implementation of any activity. The second part of self-processes is executive in nature in relation to the first one. The research in the field of acmeology shows us the existence of many different forms and ways of manifesting such self-processes.

According to L.V. Abdalina, N.A. Filonova, the successful implementation of the identified selfprocesses can be ensured primarily by the teacher's acmeological competence, which in the research is considered as the teacher's possession of self-development technologies that ensure personal and professional growth and self-realization in life [3]. L.V. Abdalina and N.A. Filonova classify self-knowledge and selfimprovement as the main self-processes that ensure the teacher's personal and professional growth.

Today, the acmeological competence as the research subject attracts the attention of many scientists (V.I. Baydenko, N.V. Kuzmina, A.V. Khutorskoy, etc.).

In the research of L.V. Abdalina the acmeological competence is considered as the productive mastery by the teacher of self-development technologies and ensuring the personal and professional growth [3]. Thus, the provision of the teacher's personal and professional growth is carried out through his purposeful selfknowledge and self-improvement of the personality for high self-realization in the professional activity.

Ilyin V.A. in «Psychology of Leadership» combines such concepts as «professionalism of activity» and «proficiency of personality». These two concepts can be attributed to competencies that play an important role in the personal development of a professional. The degree of the personal development of a professional is determined by the concept of «leadership». He emphasizes such psychological and acmeological competences of a leader as intelligence, thinking, striving for knowledge and development of his abilities, creativity, self-confidence, purposefulness, initiative, hard work, level of communication skills, etc. [4].

Tyurin K.G. distinguishes in the modern acmeology the concept of the «acmeological ability», which, in his opinion, serves for the implementation of the acmeological activity [5]. 
The idea of life principles that can be correlated with claims, gender identity, psychological time of a personality, with its value orientations and social-normative space is determined by N.A. Nizovskikh as a means of personal self-development of an individual. In his opinion, the motivation for imitation, the need for love and recognition, the desire for independence and the enrichment of one's essential forces, selfaffirmation, self-realization, self-expression, self-improvement, achieving a sense of the fullness of existence act as the motivation for the personal self-development. Self-development is understood as a culture-like process of self-change, carried out with the help of specifically human higher mental functions and possessing the attributes of arbitrariness, sociality, mediation, and awareness. The line of human development is the process of making a cultural tool, with the help of which he will change, create, and cultivate the environment: external and internal [5].

\section{Results and Discussion}

As the analysis of scientific literature has shown, in the context of studying the problems of selfdevelopment and self-realization, the phenomenology of acmeological abilities includes the study of valuesemantic, cognitive, personal determinants of a person's abilities for self-development and their productive use by him in the context of improving his professional activity, as well as life in general [5].

One of the key tasks in the study of the acmeological paradigm is the study of internal psychological means of self-development. Based on the results of the analysis of acmeological studies, we came to the conclusion that the potential for the personality development depends on the system of internal acmeological resources of the personality, it (development) is carried out by moving along the personal and professional ladder, with the solution of regularly increasing problems. At the same time, acmeological resources are independent, voluntary and conscious use by a person of his internal characteristics.

The analysis of scientific literature on the problem of self-development (L.S. Vygotsky, A.N. Leontyev) tells us that the process of self-development and self-change is not a particularly important task for all people. Self-development will be important when there is a problem of solving complex professional and life problems. In this case, a person has to develop and rebuild himself in order to be psychologically ready to complete new professional and life tasks [5]. Self-development of an adult can be only carried out by himself. A special role in the self-development of an adult is played by setting complex tasks for him.

In addition to acmeological abilities, some people have natural special abilities such as musical, artistic, physical, and mental. These abilities also play an important role in the self-development of an individual and are realized through the inclusion of acmeological abilities.

\section{Conclusion}

Thus, summarizing all of the above, we consider the teacher's acmeological competence as the ability for self-development, which, in principle, is possessed by every person, but using the capabilities of these abilities is inherent only to those who have ambitions and are able to set themselves complex productive tasks. The task of a teacher in the trilingual education is the development of a multilingual personality. This will be facilitated by the personal and professional motivation of a teacher himself, on the path of which he needs to include self-knowledge and self-improvement, reveal his autopsychological competence and realize his acmeological abilities.

\section{References}

1 Послание Президента Республики Казахстан Н. Назарбаева народу Казахстана от 10 января 2018 г. [Электронный pecypc]. — 2018. - Режим доступа: https://www.akorda.kz/ru/addresses/addresses_of_president/poslanie-prezidenta-respublikikazahstan-n-nazarbaeva-narodu-kazahstana-10-yanvarya-2018-g.

2 Стратегический план развития Республики Казахстан до 2025 года. № 636 от 15 февраля 2018 г. [Электронный ресурс]. - 2018. - Режим доступа: akorda.kz/ru/official_documents/strategies_and_programms.

3 Абдалина Л.В. Акмеологическая компетенция преподавателя колледжа: структура и содержание / Л.В. Абдалина, Н.А. Филонова ГЭлектронный ресурс] // Вестн. ТГУ. - 2009. - № 2 (70). - С. 249-251. — Режим доступа: https://cyberleninka.ru/article/n/akmeologicheskaya-kompetentsiya-prepodavatelya-kolledzha-struktura-i-soderzhanie/viewer.

4 Ильин В.А. Психология лидерства [Электронный ресурс] / В.А. Ильин. — 2015. - Режим доступа: http://urss.ru/PDF/add_ru/191245-1.pdf.

5 Тюрин К.Г. Акмеологические способности в контексте изучения проблемы саморазвития личности профессионала / К.Г. Тюрин // Междунар. журн. Elvestnik.com. - 2016. - С. 103-107. [Электронный ресурс]. — Режим доступа: https://cyberleninka.ru/article/n/akmeologicheskie-sposobnosti-v-kontekste-izucheniya-problemy-samorazvitiya-lichnostiprofessionala/viewer. 
6 Деркач А.А. Акмеология: учеб. пос. / А.А. Деркач, В.Г. Зазыкин. - М.: РАГС, 2006.

7 Акишева А. Акмеологические основы повышения карьерного роста преподавателей системы повышения квалификации [Текст] / А. Акишева // Менеджмент в образовании. - 2015. — № 4. - С. 70-74.

8 Онищенко Ю.Ю. Формирование профессионализма учителя в системе педагогического образования в Великобритании: конец XX - начало XXI вв: дис...канд. пед. наук:13.00.01 - «Общая педагогика, история педагогики и образования»/ Юлия Юрьевна Онищенко . - Коломна, 2007. — 243 с.

9 Послание Президента Республики Казахстан Н.Назарбаева народу Казахстана «Рост благосостояния казахстанцев: повышение доходов и качества жизни» от 5 октября 2018 года // Казахстанская правда. — 2018. — № 190.

10 Филонова Н.А. Экспериментальное исследование особенностей развития акмеологической компетенции преподавателей профессионального колледжа / Н.А. Филонова // Молодой ученый. — 2009. — № 3. — С. $202-204$.

\title{
Е.А. Костина, Г.К. Тлеужанова, Д.К. Джолданова \\ Үштілді білім беру жағдайында мұғалімнің акмеологиялық құзыреттілігінің рөлі
}

\begin{abstract}
Мақалада «акмеологиялық құзыреттілік» түсінігі және оның үштілді білім беру жағдайындағы рөлі зерттелген. Үштілді білім беру саясаты сипатталған, орта мектеп мұғалімдерінің ағылшын тілін меңгеру деңгейлерінің жеткіліксіздігі байқалады және көптілді жеке тұлғаны дамыту керектігі айқындалған. Авторлар осы қажетті жүзеге асыру үшін, өзін-өзі жүзеге асыру, өзін-өзі дамыту және жетілдіру сияқты, жеке қасиеттердің дамуына түрткі болатын, акмеологиялық құзыреттіліксіз мүмкін емес деген қорытындыға келеді. Бұл жерде, кәсіби қызметте жақсы нәтижелерге жету үшін, жеке тұлға өзін-өзі әрдайым дамыту керек екені айтылады. Алайда өзін-өзі жүзеге асыру, өзін-өзі дамыту, өзін-өзі жетілдіру үдерістері барлық адамдар үшін ерекше маңызды міндеттер емес. Бұл үдерістер, адам кәсіби немесе өмірлік мәселелерді шешу проблемасына тап болған кезде, маңызды болады. Осылайша, авторлар әрбір ересек адамның жеке және кәсіби өсуіне қол жеткізу үшін, өзіне қиын міндеттер қоюы керек екендігін атап көрсетеді. Мақалада акмеологиялық құзыреттіліктен басқа «акмеологиялық қабілет», «іс-әрекеттің кәсіпқойлығы» және «жеке тұлғаның кәсіпқойлығы» сияқты ұғымдар қарастырылған, олар да кәсіби қалыптасу мен тұлғаның дамуында маңызды рөл атқарады. Жалпы, авторлардың пікірі бойынша, үштілді білім берудегі міндет болып табылатын көптілді тұлғаны дамыту, мұғалімнен кәсіби іс-әрекетте жоғары мотивацияны талап етеді.
\end{abstract}

Кілт сөздер: акмеологиялық құзыреттілік, үштілді білім беру, акмеологиялық қабілеттілік, көпмәдениетті және көптілді жеке тұлға.

\section{Е.А. Костина, Г.К. Тлеужанова, Д.К. Джолданова}

\section{Роль акмеологической компетенции педагога в условиях трехъязычного образования}

В статье рассмотрены понятие «акмеологическая компетенция» и ее роль в условиях трехъязычного образования. Описана политика трехъязычного образования, отмечена недостаточность уровня владения английским языком учителями средних школ и выявлена необходимость развития полиязыковой личности. Авторами сделаны выводы относительно того, что для реализации данной необходимости невозможно обойтись без акмеологической компетенции, которая стимулирует развитие таких личностных качеств, как самореализация, саморазвитие и самосовершенствование. Это говорит о том, что личность должна себя постоянно развивать, чтобы добиться хороших результатов в профессиональной деятельности. Однако процессы самореализации, саморазвития и самосовершенствования являются не для всех людей особо важными задачами. Эти процессы становятся значимыми в том случае, когда перед личностью появляется проблема решения профессиональных или жизненных задач. Таким образом, авторы выделяют тот факт, что каждый взрослый человек должен ставить перед собой сложные задачи, чтобы достичь личностно-профессионального роста. Помимо акмеологической компетенции, в статье рассмотрены такие понятия, как «акмеологическая способность», «профессионализм деятельности» и «профессионализм личности», которые также играют важную роль в профессиональном становлении и развитии личности. В общем, по мнению авторов, развитие полиязыковой личности, которая является задачей в условиях трехъязычного образования, требует от педагога высокой мотивации в профессиональной деятельности.

Ключевые слова: акмеологическая компетенция, трехъязычное образование, акмеологическая способность, поликультурная и полиязыковая личность. 


\section{References}

1 Poslanie Prezidenta Respubliki Kazakhstan N. Nazarbaeva narodu Kazakhstana. 10 yanvaria 2018 hoda [Message of the President of the Republic of Kazakhstan N. Nazarbayev to the people of Kazakhstan. January 10, 2018$]$ [Electronic resource]. 2018. - Access mode: https://www.akorda.kz/ru/addresses/addresses_of_president/poslanie-prezidenta-respubliki-kazahstan-nnazarbaeva-narodu-kazahstana-10-yanvarya-2018-g [in Russian].

2 Stratehicheskii plan razvitiia Respubliki Kazakhstan do 2025 hoda. No 636 ot 15 fevralia 2018 hoda [Strategic development plan of the Republic of Kazakhstan until 2025 No. 636 dated February 15, 2018 ] [Electronic resource]. — 2018. — Access mode: akorda.kz/ru/official_documents/strategies_and_programms [in Russian].

3 Abdalina L.V., \& Filonova, N.A. (2009). Akmeolohicheskaia kompetentsia prepodovatelia kolledzha: struktura i soderzhanie [Acmeological competence of a college teacher: structure and content] [Electronic resource] // Bulletin of Tomsk State University. - No. 2 (70). - P. 249-251. - Access mode: https://cyberleninka.ru/article/n/akmeologicheskaya-kompetentsiya-prepodavatelyakolledzha-struktura-i-soderzhanie/viewer [in Russian].

4 Ilyin, V.A. (2015). Psikholohiia liderstva [Psychology of leadership] [Electronic resource]. Access mode: http://urss.ru/PDF/add_ru/191245-1.pdf [in Russian].

5 Tyurin, K.G. (2016). Akmeolohicheskie sposobnosti v kontekste izuchenia problemy samorazvitiia lichnosti professionala [Acmeological abilities in the context of studying the problem of self-development of a professional's personality] // International Journal Elvestnik.com.[Electronic resource]. - Access mode: https://cyberleninka.ru/article/n/akmeologicheskie-sposobnosti-vkontekste-izucheniya-problemy-samorazvitiya-lichnosti-professionala/viewer [in Russian].

6 Derkach, A.A., \& Zazykin, V.G. (2006). Akmeolohiia: uchebnoe posobie [Acmeology: textbook]. Moscow: RAGS [in Russian].

7 Akisheva, A. (2015). Akmeolohicheskie osnovy povysheniia karernoho rosta prepodavatelei sistemy povysheniia kvalifikatsii [Tekst] [Akmeological foundations of career advancement for teachers of the advanced training system [Text]] // Management in education [in Russian].

8 Onishchenko, Yu.Yu. (2007). Formirovanie professionalizma uchitelia $v$ sisteme pedahohicheskoho obrazovaniia $v$ Velikobritanii: konets XX - nachalo XXI vv: dissertatsiia ... kandidata pedahohocheskikh nauk: 13.00 .01 - "Obshchaia pedahohika, istoriia pedahohiki i obrazovaniia»[Formation of teacher professionalism in the system of teacher education in the UK: late XX - early XXI centuries: dis... cand. ped. sciences: 13.00.01 — "General pedagogy, history of pedagogy and education»] [in Russian].

9 Poslanie Prezidenta Respubliki Kazakhstan N. Nazarbaeva narodu Kazakhstana «Rost blahosostoianiia kazakhstantsev: povyshenie dokhodov i kachestva zhizni» ot 5 oktiabria 2018 hoda [Message of the President of the Republic of Kazakhstan $N$. Nazarbayev to the people of Kazakhstan "Growth in the prosperity of Kazakhstanis: increasing income and quality of life» dated October 5, 2018]. Kazakhstanskaia Pravda [in Russian].

10 Filonova, N.A. (2009). Eksperimentalnoe issledovanie osobennostei razvitiia akmeolohicheskoi kompetentsii prepodovatelei professionalnoho kolledzha [Experimental study of the peculiarities of the development of acmeological competence of teachers of a professional college]. Molodoi uchenyi, 3, 202-24 [in Russian]. 